\title{
Tokyo takes steps toward "genetic" food labeling
}

It looks possible that the Japanese authorities will relinquish their laissez-faire policy toward foods with genetically engineered ingredients and move toward establishing rules for labeling such products. Japan's Ministry of Agriculture, Forestry, and Fisheries (MAFF; Tokyo) is likely to announce this month its preliminary plans for the labeling of food products containing genetically modified organisms (GMO). Such a move is seen by many as premature considering that a virtual standoff between consumer advocate groups and the food industry over the decision for such labeling remains unresolved.

Takeshi Watanabe, chairman of MAFF's committee on GMO food labeling said in June that the Ministry's plan will include types of targeted products, a possible method of labeling, and techniques for detecting GMOs. This suggests strongly that the ministry's intentions are to use the presence or absence of GMOs as the trigger for labeling. Further details of the plan are expected to be made public during the committee's 11 th monthly meeting to be held around the end of July and early August.

Pressure for labeling among consumer advocacy groups has intensified since last December, when it was speculated that MAFF was intending to abandon its plan to consider labeling of products containing GMOs (see Nature Biotechnology 16:121, 1998). It is thought that the ministry had been lobbied by the United States, whose food producers feared that mandatory labeling would create a trade barrier.

A wide variety of imported genetically manipulated foodstuffs already circulates in Japan. The country's low self-sufficiency of agricultural products means that it is dependent on import-for example, $80 \%$ of Japan's total soybean supply comes from the United States. The first genetically modified food import was approved in April 1996 by the Ministry of Health and Welfare's (MHW; Tokyo) Food Sanitation Investigation Council. Since then, 20 products, including maize, soybeans, and rapeseed, mostly from the United States, have so far passed MHW's food safety control.

None of these products are labeled. The Japanese government had previously maintained a position that labeling of genetically engineered foods was not necessary, arguing that GMOs are essentially the same with crossbred plants as long as the products' quality are the same. The health ministry took a similar stance by not requiring labeling of GMOs as long as the products satisfy the standards set by the food safety law.
However, in May 1997, MAFF created a new committee consisting of representatives from the scientific community, consumer groups, and the food industry in order to explore the possibility of labeling genetically modified food products.

Although the move was seen as a significant step toward joining the international trend of tackling the issue, conflicting opinions between committee members made reaching consensus difficult. Representatives from consumer organizations demanded labeling of all genetically engineered foods, but industry representatives opposed their plans strongly, arguing that the best they could achieve is an introduction of labels that indicate the nonuse of GMOs.

Standards set by other countries, such as the United States and the European Union (EU), are also likely to affect the ministry's final decision. The recent failure by the UN/World Health Organization Codex Alimentarius (Nutrition Code) Commission, an international organization that sets food standards, to agree to mandatory labeling of GMOs is seen as a setback to consumer groups. "It would be a disgrace if the Japanese government fails to represent the nation's view in their future policy," says Yasue Sato, director-general, Consumption Science Federation and member of the GMO labeling committee. "It is important to recognize the right of consumers to know what they are eating."

Awareness of genetically engineered food, however, is still low in Japan compared with other countries. A public opinion survey held last November by MAFF showed that approximately $50 \%$ of 3000 people surveyed have limited knowledge of genetically engineered foods and $63 \%$ were oblivious to the fact that products containing GMOs were already being sold in Japan.

Mitsuru Miyata of the biotechnology newsletter Nikkei Biotechnology (Tokyo) attributes limited public knowledge about GMOs to the fact that its dominant market is outside Japan. "Since all GMOs are imported from overseas, there is no direct benefit to the agricultural industry, and consumers still find difficulty with what the benefit and risks of GMOs are. As long as the food is safe, they'll eat it," he says.

Many of the committee members have expressed difficulty in adopting a system similar to that of the $\mathrm{EU}$, whose new rules force manufacturers to label products containing genetically modified soya and maize. They cite the difficulty in tracing back original ingredients in processed food, and Japan's high dependence on imported products as the main reason to reject the EU model.

"The new proposals will hopefully be a step up toward reaching a definitive consensus," says a MAFF spokesman. He says that the ministry itself is taking a neutral stance on the issue, and that the final decision is left to the food labeling committee to decide.

Asako Saegusa

\section{Science-free GM food tests advance}

A European Council regulation stipulating that any food product made from some maize and soya varieties containing "foreign" DNA or proteins must be labeled accordingly (Nature Biotechnology 16:605, 1998) comes into force in September. In effect, the regulation means that all soya and corn from the United States, and possibly all prepared foods containing them, will have to be tested, creating what some regard as a substantial new and unscientific barrier to trade. There are, however, no officially approved tests on the market that would allow food companies to test for molecules from genetically modified organisms in their ingredients, no standards protocols outlined, and the lower limit for testing has yet to be defined.

Ellen Peerenboom is a freelance writer working in Cologne, Germany.
The environmental organization Greenpeace thinks the new regulation is "a disaster for food manufacturers," and that it "will fail in practice." According to Benedikt Härlin, coordinator of the genetic engineering campaign for Greenpeace Europe (Amsterdam), "There should not be an analysis of the food product-which will exclude certain products such as oil right away-[but] labeling that will allow certification according to the process used." Härlin says that until the European Commission (EC; Brussels, Belgium) formulates a better regulation, as Greenpeace hopes it will, the organization will seek to expose products that are incorrectly labeled. "We will make it public if an unlabeled product contains GMOs [genetically modified organisms]," he says.

Although some companies, such as Central Soya (Fort Wayne, IN), offer certificates of origin to food producers, the system 